Agr. Biol. Chem., 39 (5), $931 \sim 938,1975$

\title{
Supplemental Effects of Arginine and Methionine on Growth, and on Formations of Urea and Creatine of Adrenalectomized Rats Fed High Glycine Diets
}

\author{
Hisanao TaKeuchI, Motoshi Isobe, Shoji UsuI and Keiichiro Muramatsu \\ Depatment of Agricultural Chemistry, Faculty of Agriculture, \\ Shizuoka University, Oya, Shizuoka \\ Received August 12, 1974
}

\begin{abstract}
The effects of adrenalectomy on growth, some enzyme activities in the liver and kidney, and urinary excretion of urea, creatinine and creatine were investigated in rats fed the $10 \%$ casein diets containing $7 \%$ glycine with or without $\mathrm{L}$-arginine and L-methionine $(10 \mathrm{C}, 10 \mathrm{C} 7 \mathrm{G}$ and 10C7ArgMet).

Body weight gains of the intact $10 \mathrm{C}$ and $10 \mathrm{C} 7 \mathrm{GArgMet}$ groups were almost same as the corresponding adrenalectomized groups. The body weight of the adrenalectomized 10C7G group was extremely decreased though that of the intact $10 \mathrm{C} 7 \mathrm{G}$ group was maintained almost constant; but the decrease was recovered by the administration of hydrocortisone. The activities of liver arginase and carbamylphosphate synthetase were not affected by those diets. Liver serine dehydratase and ornithine $\delta$-aminotransferase activities were increased in the intact $10 \mathrm{C} 7 \mathrm{G}$ and 10C7GArgMet groups, but these increases were depressed by adrenalectomy. Glutamate-pyruvate transminase activities in the liver of intact 10C7G and 10C7GArgMet groups were also enhanced, but were extremely decreased in the corresponding adrenalectomized groups. Kidney transamidinase activity was not affected by adrenalectomy. The amount of urinary excreted urea was almost unchanged by adrenalectomy, but was increased by hydrocortisone administration. The amounts of excreted creatine of the adrenalectomized groups were generally larger than the corresponding intact groups, but slightly decreased by the ad ministration of hydrocortisone. The amount of excreted creatinine was not generally affected by adrenalectomy.
\end{abstract}

Previous reports ${ }^{1 \sim 3)}$ showed that urinary excreted creatine and urea, and the activities of liver serine dehydratase and glutamate-pyruvate transaminase in rats were increased by the feeding of the $10 \%$ casein diet containing excess glycine, and furthermore enhanced by the supplementations of arginine and methionine to the excess glycine diet. These enzyme activities $^{4 \sim 9)}$ in the liver have also been reported to be decreased by adrenalectomy, but recovered by the administration of glucocorticoids to adrenalectomized rats. It has also been demonstrated that hypophysectomy leads to the depression of the activities of liver serine dehydratase $\mathrm{e}^{10)}$ and kidney transamidinase ${ }^{11)}$ in rats. These observations suggest that the preventive effect of arginine and methionine for the depressions of growth and food intake in rats fed the excess glycine diet $^{2,12)}$ may be caused through hormonal actions.

In the present paper, the changes in body weight, the formations of creatine and urea, and the activities of liver urea cycle enzymesarginase and carbamylphosphate synthetase, and amino acid catabolizing enzymes - serine dehydratase, ornithine $\delta$-aminotransferase and glutamate-pyruvate transaminase were studied in adrenalectomized rats fed excess glycine diets.

\section{MATERIALS AND METHODS}

Animals and diets. Male rats of the Donryu strain fed a stock diet ( $25 \%$ casein), weighing 90 to $115 \mathrm{~g}$, were adrenalectomized in the back and further given the same diet for 3 days. The intact and the operated animals having 90 to $120 \mathrm{~g}$ of body weight were separated into two series of experiments.

Expt. I. The intact and the adrenalectomized rats 
weighing 100 to $130 \mathrm{~g}$ were divided into 3 groups of 3 to 4 rats each. Three groups were as follows: $10 \%$ casein $(10 \mathrm{C}), 10 \%$ casein plus $7 \%$ glycine $(10 \mathrm{C} 7 \mathrm{G})$, and $10 \mathrm{C} 7 \mathrm{G}$ plus $1.4 \% \mathrm{~L}$-arginine $\mathrm{HCl}$ and $0.9 \% \mathrm{~L}$ methionine (10C7GArgMet) of which supplemented amounts were simulated to levels in a $30 \%$ casein diet as reported previously. ${ }^{12}$ The composition of the $10 \%$ casein diet was described in the previous work. ${ }^{121}$ Each test diet was given ad libitum for 10 days.

Expt. $I$. The intact and the adrenalectomized animals having 90 to $100 \mathrm{~g}$ of body weight were separated 3 and 6 groups of 3 to 4 rats each. Half of the operated groups was given twice a day intraperitoneal injection of $0.5 \mathrm{mg}$ of hydrocortisone acetate* per $100 \mathrm{~g}$ of body weight. The same diets as Expt. I were used. The food intake of each group was adjusted to that of the adrenalectomized rats fed the $10 \mathrm{C} 7 \mathrm{G}$ diet, which showed the least food consumption for 7 days.

In both experiments, each diet was given in the form of a dumpling and the adrenalectomized rats received ad libitum $0.9 \%$ sodium chloride solution in place of water.

Analysis. In Expt. I, the urine was collected into with distilled water. Rats were killed by decapitation $3 \mathrm{hr}$ after the last feeding. The blood was collected into a heparinized glass tube. The liver and kidney were quickly removed and homogenized with 4 parts of ice-cold $0.1 \mathrm{M}$ phosphate buffer (pH 7.4). The activities of liver serine dehydratase, ${ }^{14)}$ glutamate-pyruvate transaminase, ${ }^{3)}$ ornithine $\delta$-aminotransferase, ${ }^{14)}$ arginase, ${ }^{16)}$ carbamylphosphate synthetase ${ }^{15)}$ and kidney transamidinase, ${ }^{12)}$ and urinary excreted urea ${ }^{31}$ and creatine ${ }^{1 /}$ were assayed according to the previous reports.

\section{RESULTS}

\section{Body weight and food intake}

Body weight gain, food intake and liver weight of the intact and the adrenalectomized rats fed ad libitum the $10 \mathrm{C}, 10 \mathrm{C} 7 \mathrm{G}$ and $10 \mathrm{C}$ 7GArgMet (Expt. I, ad libitum feeding) are shown in Table I. As reported previously, ${ }^{3,12}$, the body weight gain of the intact 10C7GArgMet group was equal to that of the intact $10 \mathrm{C}$ group, but that of the intact $10 \mathrm{C} 7 \mathrm{G}$ group was

Table I. Body Weight Change, Food Intake, Ltver Weight and Kidney Weight of Intact and Adrenalectomized Rats Fed Ad Libitum the 10\% Casein Diets Containing $7 \%$ Glycine FOR 10 DAYS (Expt. I)

\begin{tabular}{|c|c|c|c|c|c|}
\hline Treatment & $\begin{array}{l}\text { Dietary group } \\
\text { (symbol) }\end{array}$ & $\begin{array}{l}\text { Body weight } \\
\text { change } \\
\text { g/10 days }\end{array}$ & $\begin{array}{l}\text { Food } \\
\text { intake } \\
\mathrm{g} / 10 \text { days }\end{array}$ & $\begin{array}{l}\text { Liver } \\
\text { weight } \\
\mathrm{g}\end{array}$ & $\begin{array}{l}\text { Kidney } \\
\text { weight } \\
\text { g }\end{array}$ \\
\hline \multirow{4}{*}{ Intact } & $10 \%$ Casein $(10 \mathrm{C})$ & $26.8 \pm 2.7^{3 / a}$ & $107 \pm 15^{a}$ & $4.22 \pm 0.40$ & $1.29 \pm 0.05$ \\
\hline & $+7 \%$ Gly $(10 \mathrm{C} 7 \mathrm{G})$ & $5.6 \pm 1.4^{b c}$ & $76 \pm 7^{6}$ & $5.09 \pm 0.37$ & $1.18 \pm 0.03$ \\
\hline & $+7 \%$ Gly $+1.4 \%$ & & & & \\
\hline & $\begin{array}{c}\mathrm{L}-\mathrm{Arg} \cdot \mathrm{HCl}^{11} \\
+0.9 \% \mathrm{~L}-\mathrm{Met}^{1 \prime} \\
(10 \mathrm{C} 7 \mathrm{GArgMet})\end{array}$ & $27.9 \pm 5.3^{a}$ & $109 \pm 14^{a}$ & $5.76 \pm 0.65$ & $1.44 \pm 0.18$ \\
\hline \multirow{5}{*}{ Adrenalectomy } & $10 \mathrm{C}$ & $21.8 \pm 2.3^{a}$ & $113 \pm 5^{a}$ & $4.95 \pm 0.22$ & $1.26 \pm 0.03$ \\
\hline & $10 \mathrm{C} 7 \mathrm{G}$ & $-13.3 \pm 8.8^{d}$ & $61 \pm 15^{b}$ & $4.66 \pm 0.35^{a}$ & $1.24 \pm 0.13$ \\
\hline & $10 \mathrm{C} 7 \mathrm{G}+$ & & & & \\
\hline & Hydrocortisone $^{2}$ & $2.7 \pm 2.1^{b c}$ & $93 \pm 13^{a}$ & $7.02 \pm 0.84^{b}$ & $1.55 \pm 0.14$ \\
\hline & 10C7GArgMet & $25.8 \pm 6.4^{a}$ & $101 \pm 12^{a}$ & $5.40 \pm 0.41$ & $1.69 \pm 0.12$ \\
\hline
\end{tabular}

1) $\mathrm{L}$ - $\mathrm{Arg} \cdot \mathrm{HCl}(1.4 \%)$ and $\mathrm{L}-\mathrm{Met}(0.9 \%)$ equal the contents of $\mathrm{L}$-arginine and $\mathrm{L}$-methionine in a $30 \%$ casein diet.

2) Hydrocortisone acetate, $0.5 \mathrm{mg}$ per $100 \mathrm{~g}$ of body weight was injected intraperitoneally twice a day for 10 days.

3) Mean \pm SE. Significant difference between the superscripts of ${ }^{a}$ and ${ }^{b}$ and between the superscripts of ${ }^{c}$ and $d$ at $P<0.05$.

a bottle containing $10 \mathrm{ml}$ of $0.1 \mathrm{~N}$ sulfuric acid during the last 2 days. The urine in Expt. II was collected during 2 days after the start of feeding test diets and before killing. The urine was then diluted to $250 \mathrm{ml}$

\footnotetext{
* Nippon Merck Banyu Co., Ltd., Tokyo.
}

remarkably less than the other groups. The weight gains of the adrenalectomized $10 \mathrm{C}$ and 10C7GArgMet groups were not much different from those of the corresponding intact groups, while the body weight of the adrenale- 
ctomized 10C7G group was markedly decreased; but this decrease was recovered by the administration of hydrocortisone. Food intake of each group was almost proportional to each weight change, but that of the operated $10 \mathrm{C} 7 \mathrm{G}$ group administered hydrocortisone was large in spite of remarkably small weight gain of the group. The result consists with the reports $^{16 \sim 18)}$ that the body weights of rats fed the casein diets were decreased by the administration of glucocorticoids. The liver weight of the hydrocortisone-injected adrenalectomized $10 \mathrm{C} 7 \mathrm{G}$ group was markedly larger than those of the other groups.

Table II shows the body weight changes and food intakes of the intact and the adrenalectomized rats restrictively given the test diets for 7 days (Expt. II, restrictively feeding). Though the amount of diets administered to each group was adjusted equal to that of the adrenalectomized $10 \mathrm{C} 7 \mathrm{G}$ group, the weight gains of the intact and the operated $10 \mathrm{C} 7 \mathrm{G}$ ArgMet groups were slightly larger, and those of the operated groups with hydrocortisone injection were a little less than those of the other groups.

\section{Liver enzyme activities}

The activities of liver enzymes of each group in Expt. I (ad libitum feeding) are shown in Table III. The activities of liver arginase and carbamylphosphate synthetase were not much different among each diet group, but those of the adrenalectomized groups were smaller than those of the intact groups. Freedland ${ }^{8)}$ and Shimke $^{19)}$ also reported that these enzyme activities were decreased by adrenalectomy. However, the administration of hydrocortisone to the operated $10 \mathrm{C} 7 \mathrm{G}$ group enhanced those enzyme activities, which was similar to Shimke's result. ${ }^{19}$.

The activities of liver serine dehydratase and ornithine $\delta$-aminotransferase were increased in the intact $10 \mathrm{C} 7 \mathrm{G}$ group and furthermore enhanced in the intact 10C7GArgMet group, which was consistent with the previous report. ${ }^{31}$ These enzyme activities of the adrenalectomized $10 \mathrm{C} 7 \mathrm{G}$ and $10 \mathrm{C} 7 \mathrm{GArgMet}$ groups were smaller than those of the corresponding intact groups, but much larger than the intact $10 \mathrm{C}$ group, and yet there was not different between both the excess glycine groups. However, those activities were extremely increased by administering

Table II. Body Weight Change and Food Intake of Intact and Adrenalectomized Rats Fed Restrictively the Casein Diets Containing 7\% Glycine with or without HYDROCORTISONE INJECTION FOR 7 DAYS (EXpt. II)

\begin{tabular}{|c|c|c|c|}
\hline Treatment & $\begin{array}{l}\text { Dietary group } \\
\quad \text { (symbol) }\end{array}$ & $\begin{array}{c}\text { Body weight } \\
\text { change } \\
\mathrm{g} / 7 \text { days }\end{array}$ & $\begin{array}{l}\text { Food } \\
\text { intake } \\
\mathrm{g} / 7 \text { days }\end{array}$ \\
\hline \multirow{6}{*}{ Intact } & $10 \%$ Casein $(10 \mathrm{C})$ & $0.3 \pm 0.4^{31}$ & $52.0 \pm 6.6$ \\
\hline & $+7 \%$ Gly $(10 \mathrm{C} 7 \mathrm{G})$ & $0.0 \pm 1.9$ & $50.4 \pm 2.5$ \\
\hline & $+7 \%$ Gly $+1.4 \%$ & & \\
\hline & $\mathrm{L}-\mathrm{Arg} \cdot \mathrm{HCl}^{11}$ & $8.0 \pm 2.1$ & $56.5 \pm 1.9$ \\
\hline & $+0.9 \%$ L-Met ${ }^{1)}$ (10C7GArgMet) & & \\
\hline & $10 \mathrm{C}$ & $-3.0 \pm 2.8^{a}$ & $47.7 \pm 0.8$ \\
\hline \multirow{2}{*}{ Adrenalectomy } & $10 \mathrm{C} 7 \mathrm{G}$ & $1.0 \pm 2.3^{\circ}$ & $44.7 \pm 2.3$ \\
\hline & 10C7GArgMet & $9.0 \pm 6.4^{e}$ & $55.4 \pm 1.2$ \\
\hline Adrenalectomy & $10 \mathrm{C}$ & $-9.7 \pm 2.6^{b}$ & $49.8 \pm 0.8$ \\
\hline+ & $10 C 7 \mathrm{G}$ & $-10.3 \pm 2.2^{d}$ & $50.1 \pm 0.8$ \\
\hline Hydrocortisone ${ }^{21}$ & 10C7GArgMet & $-3.0 \pm 2.5^{f}$ & $52.7 \pm 1.1$ \\
\hline
\end{tabular}

1) L-Arg $\cdot \mathrm{HCl}(1.4 \%)$ and L-Met $(0.9 \%)$ equal the contents of L-arginine and L-methionine in a $30 \%$ casein diet.

2) Hydrocortisone acetate, $0.5 \mathrm{mg}$ per $100 \mathrm{~g}$ of body weight was injected intraperitoneally twice a day for 7 days.

3) Mean \pm SE. Significant difference between the superscripts of ${ }^{a}$ and ${ }^{b}$, ${ }^{c}$ and ${ }^{d}$, and ${ }^{e}$ and $f$ at $P<0.05$, respectively. 


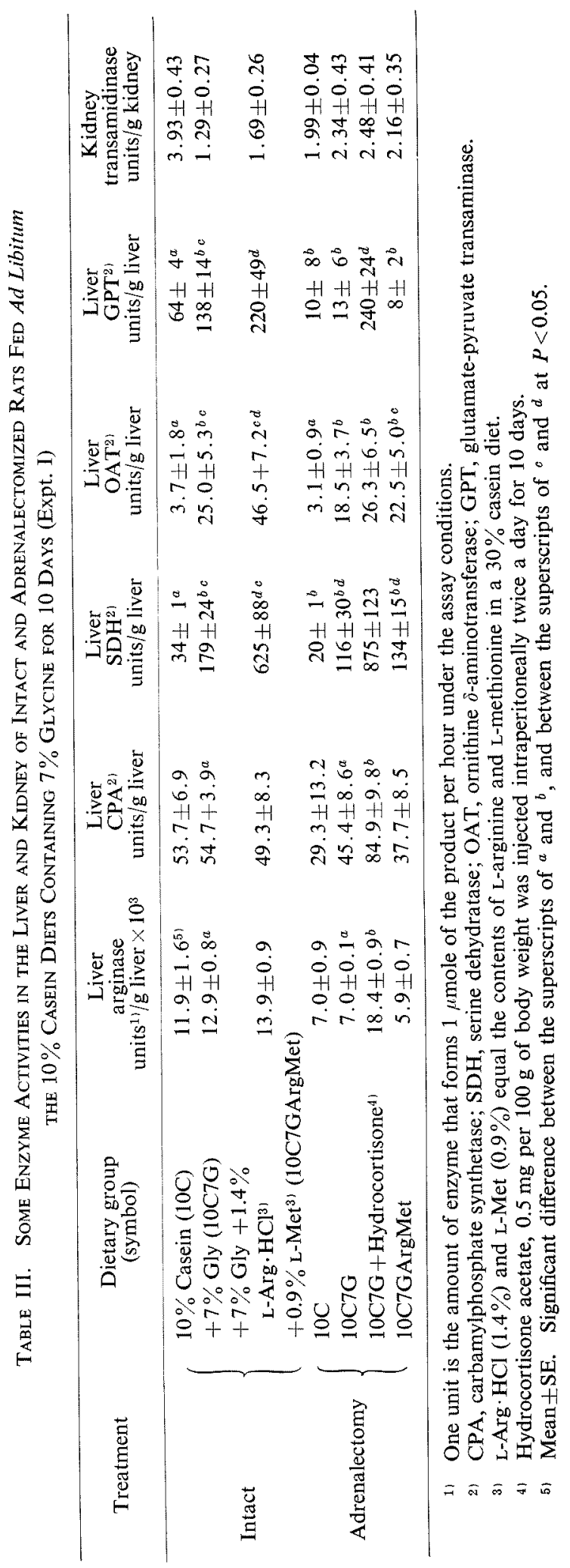


hydrocortisone to the operated rats. Other workers $^{6 \sim 8,20)}$ also reported that these enzyme activities were decreased by adrenalectomy and enhanced by the administration of glucocorticoids to the intact and the adrenalectomized rats.

Dietary effects on liver glutamate-pyruvate transaminase activities of the intact groups were similar to those of serine dehydratase activity, but the enzyme activity of the adrenalectomized rats was extremely decreased and yet not increased by feeding the $10 \mathrm{C} 7 \mathrm{G}$ or 10C7GAgrMet diets. However, this enzyme activity was also enhanced by the injection of hydrocortisone to the operated rats.

Kidney transamidinase activity was highest in the intact $10 \mathrm{C}$ group, and generally same among the other groups.

Urinary excreted urea, creatinine and creatine

Table IV shows the amounts of urinary excreted urea, creatine, creatinine and glycine of
That of each adrenalectomized group was not much different from the corresponding intact groups as an other report, ${ }^{16)}$ but the administration of hydrocortisone to the operated $10 \mathrm{C} 7 \mathrm{G}$ group increased extremely the amount of urinary urea. The amount of urinary excreted creatinine was also not much different among all of the intact and the operated groups. The creatine amount excreted in the urine of the intact groups became gradually large in the order of the 10C, 10C7G and 10C7GArgMet groups, which consisted with the previous paper. ${ }^{12)}$ The amounts of urinary creatine of the operated $10 \mathrm{C}$ and $10 \mathrm{C} 7 \mathrm{G}$ groups were larger than those of the intact $10 \mathrm{C}$ and $10 \mathrm{C} 7 \mathrm{G}$ groups, respectively; but there was no difference between the intact and the operated $10 \mathrm{C} 7 \mathrm{G}$ ArgMet groups. Prager and Talesmik ${ }^{22}$ also reported the increase of urinary excreted creatine by adrenalectomy. By the administration of hydrocortisone to the operated rats fed the $10 \mathrm{C} 7 \mathrm{G}$ diet, the excretion of uri-

Table IV. Urinary Excreted Urea, Creatine and Creatinine of Intact and Adrenalectomized Rats Fed Ad Libitum the $10 \%$ Casein Diets CONTAINING 7\% GLyCINE For 10 Days (Expt. I)

\begin{tabular}{|c|c|c|c|c|}
\hline Treatment & $\begin{array}{l}\text { Dietary group } \\
\text { (symbol) }\end{array}$ & $\begin{array}{l}\text { Urinary } \\
\text { urea }\end{array}$ & $\begin{array}{l}\text { Urinary } \\
\text { creatine } \\
100 \mathrm{~g} \text { body weigh }\end{array}$ & $\begin{array}{l}\text { Urinary } \\
\text { creatinine } \\
\text { t/day }\end{array}$ \\
\hline \multirow{3}{*}{ Intact } & $10 \%$ Casein $(10 \mathrm{C})$ & $117 \pm 15^{31 a}$ & $0.16 \pm 0.11^{a}$ & $1.16 \pm 0.18$ \\
\hline & $+7 \%$ Gly $(10 \mathrm{C} 7 \mathrm{G})$ & $177 \pm 41^{b e}$ & $0.91 \pm 0.18^{b c}$ & $1.24 \pm 0.36$ \\
\hline & $\left\{\begin{array}{l}+7 \% \text { Gly }+1.4 \% \text { L-Arg } \cdot \mathrm{HCl}^{1)} \\
+0.9 \% \mathrm{~L}^{\prime} \mathrm{Met}^{1 /}(10 \mathrm{C} 7 \mathrm{GArgMet})\end{array}\right.$ & $247 \pm 65^{b}$ & $1.78 \pm 0.51^{d}$ & $1.38 \pm 0.30$ \\
\hline \multirow{4}{*}{ Adrenalectomy } & $10 \mathrm{C}$ & $107 \pm 26^{a}$ & $0.91 \pm 0.31^{b c}$ & $1.17 \pm 0.32$ \\
\hline & $10 \mathrm{C} 7 \mathrm{G}$ & $176 \pm 15^{b c}$ & $1.71 \pm 0.33^{d}$ & $1.38 \pm 0.38$ \\
\hline & $10 \mathrm{C} 7 \mathrm{G}+\mathrm{Hydrocortisone} \mathrm{e}^{28}$ & $559 \pm 54^{d}$ & $0.29 \pm 0.33^{a}$ & $1.51 \pm 0.24$ \\
\hline & 10C7GArgMet & $191 \pm 28^{b c}$ & $1.62 \pm 0.41^{d}$ & $1.53 \pm 0.20$ \\
\hline
\end{tabular}

1) $\mathrm{L}$-Arg $\cdot \mathrm{HCl}(1.4 \%)$ and L-Met $(0.9 \%)$ equal the contents of L-arginine and L-methionine in a $30 \%$ casein diet.

2) Hydrocortisone acetate, $0.5 \mathrm{mg}$ per $100 \mathrm{~g}$ body weight was injected intraperitoneally twice a day for 10 days.

a) Mean \pm SE. Significant difference between the superscripts of ${ }^{a}$ and ${ }^{b}$, and between the superscripts of ${ }^{c}$ and ${ }^{d}$ at $P<0.05$.

each group in Expt. I (ad libitum feeding). The amount of urinary urea was increased in the order of intact $10 \mathrm{C}, 10 \mathrm{C} 7 \mathrm{G}$ and $10 \mathrm{C} 7 \mathrm{G}$ ArgMet groups, which was consistent with the previous work. $^{31}$ Other investigators ${ }^{21)}$ also reported that the addition of $7.5 \%$ glycine to the $10 \%$ casein diet increased urinary urea. nary creatine was remarkably decreased. This result was different from that the urinary excretion of urea increased by hydrocortisone administration.

The urinary excreted urea, creatinine and creatine of each group in Expt. II (restrictive feeding) are shown in Table V. The amounts 


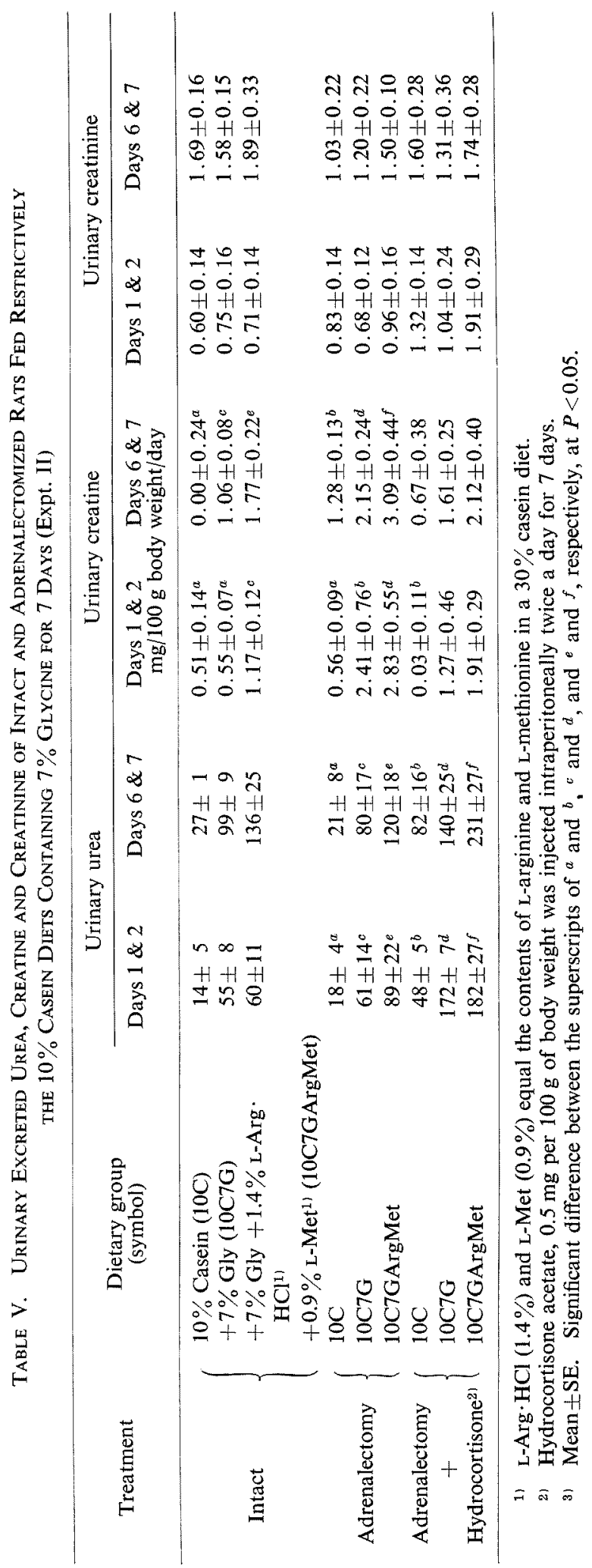


of urinary urea of the intact and the adrenalectomized groups in the final 2-day period of feeding were larger than those of the corresponding groups in the first 2-day period of feeding. The amount of urinary urea in the final 2-day period of feeding was also inclined to be increased in the order of the $10 \mathrm{C}, 10 \mathrm{C} 7 \mathrm{G}$ and 10C7GArgMet groups in the intact and the adrenalectomized. The administration of hydrocortisone to the operated groups fed any of the test diets enhanced the amount of urea. The amounts of excreted creatinine of the intact and the operated groups with or without hydrocortisone injection in the last 2-day period of feeding were greater than those of the corresponding groups in the first 2-day period. However, creatinine excretion was not markedly different among nearly all the intact and the operated groups. In the intact groups, the amount of excreted creatine was greater in the $10 \mathrm{C} 7 \mathrm{G}$ group and furthermore in the $10 \mathrm{C} 7 \mathrm{G}$ ArgMet group than that of the $10 \mathrm{C}$ as the previous works. ${ }^{2,12}$ By adrenalectomy, the amount of creatine of all groups was increased, but this increase was prevented by the administration of hydrocortisone.

\section{DISCUSSION}

The body weight of the adrenalectomized rats fed ad libitum the $10 \mathrm{C} 7 \mathrm{G}$ diet was markedly decreased though the decrease of food intake was not so much great, but the body weight and food intake of the adrenalectomized animals fed ad libitum the 10C7GArgMet diet were not different from those of the intact rats fed the same diet (Table I). These findings indicate that the preventive effect of arginine and methionine against the growth-depression by excess glycine ${ }^{12)}$ is not brought about through adrenal hormone, but the deficiency of the hormone accelerates the growth-depressive effect of excess glycine. By administering hydrocortisone to the adrenalectomized rats fed the $10 \mathrm{C} 7 \mathrm{G}$ diet, the recovery of body weight was not so much great compared with the marked increase of the food intake (Table I), and the body weight of the adrenalectomized rats fed restrictively any of the diets with administering hydrocortisone were remarkably decreased (Table II). These results suggest that hydrocortisone may accelerate the catabolism of amino acids or protein. This possibility may be supported by the enhancement of the activities of liver enzymes-arginase, ${ }^{191}$ serine dehydratase, ${ }^{6,10,23)}$ ornithine $\delta$-aminotransferase ${ }^{6)}$ and glutamate-pyruvate transaminase, ${ }^{4,5,9)}$ (Table III), and the increase of urinary excreted urea ${ }^{16)}$ (Tables IV and V). The reports that the in vivo administration of glucocorticoids accelerates the catabolism of tissue protein and the gluconeogenesis in the liver, and brings about the minus $\mathrm{N}$-balance ${ }^{16 \sim 18,24)}$ may also support that hypothesis. However, the activities of liver serine dehydratase and ornithine $\delta$-aminotransferase of the $10 \mathrm{C} 7 \mathrm{G}$ and 10C7GArgMet groups were much higher even in the adrenalectomized rats than those of the intact $10 \mathrm{C}$ group (Table III). These enzyme activities were also enhanced even by feeding a high protein diet. ${ }^{6,8,9,20)}$ Ishikawa et $a{ }^{10)}$ also reported that the activities of liver serine dehydratase and ornithine $\delta$ aminotransferase were regulated by the antagonistic action of insulin and glucagon, and glucocorticoids played a role of potentiating the action of glucagon. It is suggested that the effect of L-arginine and L-methionine to prevent the growth-depression by dietary excess glycine may be brought about through glucagon.

Urinary excreted creatine was decreased by the administration of hydrocortisone to the adrenalectomized rats fed ad libitum the 10C7G diet (Table III). Creatine excreted in the urine of the adrenalectomized rats fed restrictively any of the diets with administering hydrocortisone was also inclined to be decreased, though the increase of urinary creatine was expected because the decrease of body weight was reported to result in the enhancement of creatine excretion. ${ }^{1}$ Urinary creatinine, however, was inclined to be increased (Table V). These findings may suggest that hydrocortisone depresses the synthesis of creatine or the urinary excretion of creatine. 


\section{REFERENCES}

1) H. Takeuchi, K. Hukaya, K. Narita and K. Muramatsu, Agr. Biol. Chem., 34, 1610 (1970).

2) H. Takeuchi and K. Muramatsu, ibid., 35, 1298 (1971).

3) H. Takeuchi, M. Koike and K. Muramatsu, ibid., 37, 2609 (1973).

4) F. Gavasto, A. Pileri and A. Brusca, Biochim. Biophys. Acta, 24, 250 (1957).

5) G. H. Beaton, D. M. Curry and M. J. Veen, Arch. Biochem. Biophys., 70, 288 (1957).

6) C. Peraino, J. Biol. Chem., 242, 3860 (1967).

7) R. A. Freedland, E. H. Avery and A. R. Taylor, Can. J. Biochem., 46, 141 (1968).

8) R. A. Freedland, ibid, 46, 1253 (1968).

9) F. Rosen, N. R. Roberts and C. A. Nichol, J. Biol. Chem., 234, 476 (1959).

10) E. Ishikawa and K. Nakajima, J. Biochem., 67, 685 (1970).

11) J.P. Liberti, J.C. Colla and J.F. Van Pilsum, Arch. Biochem. Biophys., 113, 718 (1966).
12) H. Takeuchi, T. Tanaka and K. Muramatsu, Agr. Biol. Chem., 33, 1161 (1969).

13) H. Takeuchi, S. Sato, Y. Kishi and K. Muramatsu, ibid., 38, 1325 (1974).

14) H. Takeuchi and E. Ishikawa, ibid., 38, 599 (1974).

15) K. Muramatsu, R. Hirata, S. Kawakishi and K. Asida, ibid., 30, 466 (1966).

16) L. Clark, J. Biol. Chem., 200, 69 (1953).

17) R. H. Silber and C. C. Porter, Endocrinology, 52, 518 (1953).

18) G. A. J. Goodlad and H. N. Munro, Biochem. J., 73, 343 (1959).

19) R. T. Shimke, J. Biol. Chem., 238, 1012 (1963).

20) Y. Otsuka, Vitamins (Japanese), 32, 494 (1965).

21) R. W. F. Hardy and C. A. Baumann, J. Nutrition, 69, 429 (1959).

22) R. Prager and J. Talesmik, Acta Physiol. Latinoam (English), 11, 10 (1961).

23) J. P. Jost, E. A. Kharirallah and H. C. Pitot, $J$. Biol. Chem., 243, 3057 (1968).

24) T. Tsushima, "Protein, Nucleic Acid and Enzyme (Japanese)," 7, 303 (1962). 